\title{
Controversial Issues on the Clinical Use of Platelet-Derived Growth Factors
}

\author{
Vicente Mirabet*1, Dolores Pérez del Caz ${ }^{2}$ and Carmen Escobedo ${ }^{3,4}$ \\ ${ }^{1}$ Cell and Tissue Bank, Centro de Transfusión de Valencia, Spain \\ ${ }^{2}$ Service of Plastic and Reconstructive Surgery, Hospital Universitari i Politecnic La Fe, Valencia, Spain \\ ${ }^{3}$ Research Foundation, Consorcio Hospital General Universitario de Valencia, Spain \\ ${ }^{4}$ Wyss Institute for Biologically Inspired Engineering Harvard University, Boston, USA
}

*Corresponding author: Vicente Mirabet, Cell and Tissue Bank, Centro de Transfusión de Valencia, Avenida del Cid, 65-A. 46104

Valencia, Spain

\section{ARTICLE INFO}

Received: 絊 December 14, 2020

Published: 慧 December 21, 2020

Citation: Vicente Mirabet, Dolores Pérez del Caz, Carmen Escobedo. Controversial Issues on the Clinical Use of PlateletDerived Growth Factors. Biomed J Sci \& Tech Res 32(4)-2020. BJSTR. MS.ID.005290.

\section{ABSTRACT}

Increased levels of growth factors and cytokines are part of the physiological response to tissue damage. Platelet activation triggers repair mechanisms that take place consecutively in a coordinated and modulated way. Thus, the uncontrolled use of these tools, based on the principle that more is better, may lead to unexpected outcomes. For this reason, as suggested by most of the systematic reviews that address this issue, its clinical use should be carried out in randomized controlled trials, with strict standardization of protocols.

Keywords: Platelet-Rich Plasma; Controversy; Processing; Clinical Use; Growth Factors

\section{Introduction}

Platelet concentrates have been commonly used in clinical practice as blood components for hemotherapy treatments. Moreover, in the last decade of the past century, its clinical use for non-transfusion application was proposed $[1,2]$. Platelets contain dense granules and $\boldsymbol{\alpha}$-granules. These latter contain bioactive substances (as cytokines, chemokines and growth factors) which play a relevant role in wound healing phases. Updating the Celsius' quadrilateral (redness, swelling, heat, and pain) these phases are hemostasis, inflammation, proliferation, and remodeling $[3,4]$. They are developed as continuous and overlapping processes under strict coordination. The content of platelet granules has been commonly used to supplement basal culture media to stimulate in vitro cell proliferation, either as serum (after blood clotting) or platelet lysate (by cryofracture) [5].

Thus, it would be reasonable to consider the therapeutic use of platelet-derived bioactive substances for the treatment of injured tissues. Nevertheless, as an easily available resource, the expansion of its use has been characterized by a limited availability of large randomized controlled trials and evidence-based indications
[6]. This paper is focused on addressing those issues that make comparative analysis of results difficult as well as those that remain controversial.

\section{Terminology}

The definition of the product is essential to establish a first level of standardization. To do this, five conditions of the final product should be considered $[7,8,9]$ :

a) Raw material: Sample of whole blood (adult, cord blood) or platelet concentrate prepared by apheresis.

b) Processing system: Open or closed system using automated method. Number and parameters (relative centrifuge force and time) of spin cycles.

c) Platelet integrity: Platelet-rich plasma obtained by suspension of platelets in plasma after centrifugation of whole blood. Growth factor-rich plasma, when the granular content of platelets is released prior to clinical use, either by platelet activation or cryofracture (as platelet lysate, indicating temperature and number of freezing/thawing cycles). 
d) Grade of platelet concentration: The efficiency of production is classified showing the recovery rate in platelets.

e) Presence of white blood cells: Depending on whether leukocytes are discarded during processing or not, the specification as poor or rich in leukocytes should be added.

f) Type of presentation: When coagulation is induced to facilitate its clinical use the term plasma can be changed by gel

\section{Whole Blood Processing}

Donors profile must be known to evaluate potential interindividual variations. Even, differences in the volume of the blood sample can condition the yield of the proceeding [10]. For this reason, other variables which should be cited are type of anticoagulant (citrate, EDTA, if used), sample volume and detailed hematimetric values. The application of high values of relative centrifugal force during the separation of blood components can lead to platelet activation and, consequently, loss of released factors in the supernatant [11]. Cavallo et al. observed that the product obtained with a single centrifugation seemed to stimulate anabolic processes while that obtained with double centrifugation promoted more catabolic pathways [12].

\section{Therapeutic Threshold Value}

One of the most cited references in this regard was reported by Marx [13], according to which a concentration of $10^{6} \mathrm{pq} / \mu \mathrm{l}$ is required to obtain a therapeutic effect, without yielding better results at higher concentrations. This assertion was later checked in an in vitro study [14]. However, in that study, $10 \%$ concentration was used as supplement of culture medium for mesenchymal cells. Thus, this concentration would correspond approximately to the basal one. Different authors have reported similar results from in vitro studies [15-23]. Some of these studies evidenced better results with the lower concentrations. Likewise, Boswell et al. [24] suggested a maximum biological threshold for platelet concentration to obtain anabolic upregulation.

\section{Anticoagulant Agent}

Citrate is well-known for maintaining the structural integrity and physiologic responsiveness of platelets $[25,26]$. Controversial results have been reported on the effect on platelet function for EDTA $[26,27]$. Regarding the efficiency in platelet count recovering, EDTA provided better yield than citrate $[10,28,29]$.

\section{Leukocytes}

Some authors support the presence of leukocytes as beneficial, but with limits for their type, concentration and status of activation [7]. In addition to increasing the yield of growth factors, leukocytes can collaborate in the antimicrobial potential, as well as regulating inflammatory response and releasing mediators with analgesic effect. Conversely, others say that could increase inflammatory response $[10,30]$.

\section{Antimicrobial Potential}

Platelets have been associated with the defense system by releasing microbicidal proteins and chemokines that share molecular structure with antimicrobial peptides (acquiring both chemotactic and microbicidal functions) [31-33]. Several authors have demonstrated this potential in deleukocyted platelet concentrates, resulting more efficient with activated platelets $[34,35]$. However, while the growth of some bacterial species is suppressed, in others the presence of platelets has a stimulating effect [36].

\section{Platelet Activation and Clotting}

Thrombin and calcium chloride are widely used to trigger clot formation $[37,38]$. But different processing systems generate different standards of structural quality in the fibrin matrix that is obtained with coagulation. Models to standardize the structure of fibrin networks have been proposed [39]. The use of thrombin for platelet activation has been associated to the inhibitory effect on cell differentiation [40]. When free zing/thawing cycles are used to platelet content releasing, the number of recommended cycles varies from 1-2 [41-43] to 3-5 cycles [44].

\section{Platelet Count and Growth Factors Concentration}

A correlation between platelet and growth factors concentrations has been observed for PRPs with significant differences in platelet concentration. However, it is more difficult to observe for shorter differences [45]. This could be the reason why there remains controversy over the relationship between these two parameters $[46,47]$. It seems that not all the factors are associated with this correlation, but there is no consensus on what they are $[48,49]$. The most significant case corresponds to vascular endothelial growth factor that is not detected by some authors [50] while its concentration is especially increased for others [37]. Differences in growth factor concentration have also been raised depending on the processing system used [51]. Part of the platelet content is released after activation in the form of micro vesicles and, therefore, it is not detectable by commonly used analysis systems [52]. These micro vesicles play an important role as cell signaling mechanisms [53-55]. The use of protocols based on double centrifugation yields a significative reduction in micro vesicles production [56].

\section{Clinical Application}

Although platelet-rich plasma is usually activated prior to infiltration, it is not clear whether this is necessary [57]. Dose (1-5 
units) and interval between administrations (weekly, monthly) are other parameters in which differences among authors are also observed [58-60].

\section{Study Design}

In general, most studies correspond to case reports or retrospective clinical studies (sometimes without a control group), rather than prospective randomized clinical trials. Also, in some cases, the use of platelet rich plasma (PRP) is compared to placebo instead to the gold standard commonly used as alternative for that clinical indication. The International Cellular Medical Society has established a guide with recommendations aimed at standardizing issues related to the clinical use of PRP [61].

\section{Conclusion}

Platelet-rich plasma is a safe therapeutic alternative, but it is not a panacea for every pathological challenge involving tissue injury. In fact, it seems to yield better outcomes in acute pathologies than in chronic ones, and in younger patients. In Biology, more is not always better.

\section{Acknowledgements}

Carmen Escobedo is funded by Conselleria de Sanitat Universal y Salut Pública (Generalitat Valenciana) under the Plan Gent de Excelencia for returning researchers with experience abroad (CDEI-01/20-D).

\section{References}

1. Marx RE, Carlson ER, Eichstaedt RM, Schimmele SR, Strauss JE, et al. (1998) Platelet-rich plasma: Growth factor enhancement for bone grafts. Oral Surg Oral Med Oral Pathol Oral Radiol Endod 85(6): 638-646.

2. Anitua E (1999) Plasma rich in growth factors: preliminary results of use in the preparation of future sites for implants. Int J Oral Maxillofac Implants 14(4): 529-535.

3. Reinke JM, Sorg H (2012) Wound repair and regeneration. Eur Surg Res 49(1): 35-43.

4. Cottrell JA, Turner JC, Arinzeh TL, O Connor JP (2016) The Biology of Bone and Ligament Healing. Foot Ankle Clin 21(4): 739-761.

5. Mirabet V, Solves P, Miñana MD, Encabo A, Carbonell-Uberos F, et al. (2008) Human platelet lysate enhances the proliferative activity of cultured human fibroblast-like cells from different tissues. Cell Tissue Bank 9(1): 1-10.

6. Gupta S, Paliczak A, Delgado D (2020) Evidence-based indications of platelet-rich plasma therapy. Expert Rev Hematol. Taylor Francis Online.

7. Dohan Ehrenfest DM, Andia I, Zumstein MA, Zhang CQ Pinto NR, et al. (2014) Classification of platelet concentrates (Platelet-Rich Plasma-PRP, Platelet-Rich Fibrin-PRF) for topical and infiltrative use in orthopedic and sports medicine: current consensus, clinical implications and perspectives. Muscles Ligaments Tendons J 4(1): 3-9.

8. Lana JFSD, Purita J, Paulus C, Huber SC, Rodrigues BL, et al. (2017) Contributions for classification of platelet rich plasma - proposal of a new classification: MARSPILL. Regen Med 12(5): 565-574.

9. Dawood AS, Salem HA (2018) Current clinical applications of plateletrich plasma in various gynecological disorders: An appraisal of theory and practice. Clin Exp Reprod Med 45(2): 67-74.
10. Pérez AG, Lana JF, Rodrigues AA, Luzo AC, Belangero WD, et al. (2014) Relevant aspects of centrifugation step in the preparation of plateletrich plasma. ISRN Hematol 2014(25).

11. Dugrillon A, Eichler H, Kern S, Kluter H (2002) Autologous concentrated platelet-rich plasma (cPRP) for local application inbone regeneration. Int J Oral Maxillofac Surg 31(6): 615-619.

12. Cavallo C, Filardo G, Mariani E, Kon E, Marcacci M, et al. (2014) Comparison of platelet-rich plasma formulations for cartilage healing: an in vitro study. J Bone Joint Surg Am 96(5): 423-429.

13. Marx RE (2001) Platelet-Rich Plasma (PRP): What is PRP and what is not PRP? In: Implant Dentistry. Lippincott Williams \& Wilkins. USA 10(4): 225-228.

14. Marx RE (2004) Platelet-rich plasma: evidence to support its use. J Oral Maxillofac Surg 62(4): 489-496.

15. Liu Y, Kalén A, Risto O, Wahlström O (2002) Fibroblast proliferation due to exposure to a platelet concentrate in vitro is $\mathrm{pH}$ dependent. Wound Repair Regen 10(5): 336-340.

16. Crespo-Diaz R, Behfar A, Butler GW, Padley DJ, SarrMG, et al. (2011) Platelet lysate consisting of a natural repair proteome supports human mesenchymal stem cell proliferation and chromosomal stability. Cell Transplant 20(6): 797-811.

17. Cholewa D, Stiehl T, Schellenberg A, Bokermann G, Joussen S, et al. (2011) Expansion of adipose mesenchymal stromal cells is affected by human platelet lysate and plating density. Cell Transplant 20(9): 14091422.

18. Barsotti MC, Losi P, Briganti E, Sanguinetti E, Magera A, et al. (2013) Effect of platelet lysate on human cells involved in different phases of wound healing. PLoS One 9(3): e84753.

19. Giusti I, D’Ascenzo S, Mancò A, Di Stefano G, Di Francesco M, et al. (2014) Platelet concentration in platelet-rich plasma affects tenocyte behavior in vitro. Biomed Res Int 2014: 630870.

20. Mazzocca AD, O'Malley M, Beitzel K, McCarthy MB, Chowaniec DM, et al. (2015) Effects of repetitive platelet-rich plasma application on human tenocyte proliferation. Orthopedics 38(1): 19-24.

21. Tavassoli-Hojjati S, Sattari M, Ghasemi T, Ahmadi R, Mashayekhi A (2016) Effect of platelet-rich plasma concentrations on the proliferation of periodontal cells: An in vitro study. Eur J Dent 10(4): 469-474.

22. Wang X, Zhang Y, Choukroun J, Ghanaati S, Miron RJ (2017) Behavior of gingival fibroblasts on titanium implant surfaces in combination with either Injectable-PRF or PRP. Int J Mol Sci 18(2): 331.

23. Nguyen PA, Pham TAV (2018) Effects of platelet-rich plasma on human gingival fibroblast proliferation and migration in vitro. J Appl Oral Sci 26: e20180077.

24. Boswell SG, Schnabel LV, Mohammed HO, Sundman EA, Minas T, et al. (2014) Increasing platelet concentrations in leukocyte-reduced plateletrich plasma decrease collagen gene synthesis in tendons. Am J Sports Med 42(1): 42-49.

25. Pignatelli P, Pulcinelli FM, Ciatti F, Pesciotti M, Sebastiani S, et al. (1995) Acid citrate dextrose (ACD)formula $\mathrm{A}$ as a new anticoagulant in the measurement of in vitro platelet aggregation. J Clin Lab Anal 9(2): 138140.

26. Lei H, Gui L, Xiao R (2009) The effect of anticoagulants on the quality and biological efficacy of platelet-rich plasma. Clin Biochem 42(13-14): $1452-1460$

27. White JG (2000) EDTA-induced changes in platelet structure and function: clot retraction. Platelets 11(1): 49-55.

28. Do Amaral RJ, da Silva NP, Haddad NF, Lopes LS, Ferreira FD, et al. (2016) Platelet-rich plasma obtained with different anticoagulants and their effect on platelet numbers and mesenchymal stromal cells behavior in vitro. Stem Cells Int 2016. 
29. Zhang N, Wang K, Li Z, Luo T (2019) Comparative study of different anticoagulants and coagulants in the evaluation of clinical application of platelet-rich plasma (PRP) standardization. Cell Tissue Bank 20(1): 61-75.

30. Anitua E, Zalduendo M, Troya M, Padilla S, Orive G (2015) Leukocyte inclusion within a platelet rich plasma-derived fibrin scaffold stimulates a more pro-inflammatory environment and alters fibrin properties. PLoS One 10(3).

31. Yount NY, Waring AJ, Gank KD, Welch WH, Kupferwasser D, et al. (2007) Structural correlates of antimicrobial efficacy in IL-8 and related human kinocidins. Biochim Biophys Acta 1768(3): 598-608.

32. Wiesner J, Vilcinskas A (2010) Antimicrobial peptides: the ancient arm of the human immune system. Virulence 1(5): 440-464.

33. Chen L, Wang C, Liu H, Liu G, Ran X (2013) Antibacterial effect of autologous platelet-rich gel derived from subjects with diabetic dermal ulcers in vitro. J Diabetes Res 2013.

34. Drago L, Bortolin M, Vassena C, Romanò CL, Taschieri S, et al. (2014) Plasma components and platelet activation are essential for the antimicrobial properties of autologous platelet-rich plasma: an in vitro study. PLoS One 9(9).

35. Mariani E, Canella V, Berlingeri A, Bielli A, Cattini L, et al. (2015) Leukocyte presence does not increase microbicidal activity of plateletrich plasma in vitro. BMC Microbiol 15(1): 149.

36. Bielecki TM, Gazdzik TS, Arendt J, Szczepanski T, Król W, et al. (2007) Antibacterial effect of autologous platelet gel enriched with growth factors and other active substances: an in vitro study. J Bone Joint Surg Br 89(3): 417-420.

37. Eppley BL, Woodell JE, Higgins J (2004) Platelet quantification and growth factor analysis from platelet-rich plasma: implications for wound healing. Plast Reconstr Surg 114(6): 1502-1508.

38. Cavallo C, Roffi A, Grigolo B, Mariani E, Pratelli L, et al. (2016) Plateletrich plasma: the choice of activation method affects the release of bioactive molecules. Biomed Res Int 2016(1): 1-7.

39. Pérez AG, Rodrigues AA, Luzo AC, Lana JF, Belangero WD, et al. (2014) Fibrin network architectures in pure platelet-rich plasma as characterized by fiberradius and correlated with clotting time. J Mater Sci Mater Med 25(8): 1967-1977.

40. Han B, Woodell-May J, Ponticiello M, Yang Z, Nimni M (2009) The effect of thrombin activation of platelet-rich plasma on demineralized bone matrix osteoinductivity. J Bone Joint Surg Am 91(6): 1459-1470.

41. Doucet C, Ernou I, Zhang Y, Llense JR, Begot L, et al. (2005) Platelet lysates promote mesenchymal stem cell expansion: a safety substitute for animal serum in cell-based therapy applications. J Cell Physiol 205(2): 228-236.

42. Baik SY, Lim YA, Kang SJ, Ahn SH, Lee WG, et al. (2014) Effects of platelet lysate preparations on the proliferation of HaCaT cells. Ann Lab Med 34(1): 43-50.

43. Laitinen A, Oja S, Kilpinen L, Kaartinen T, Möller J, et al. (2016) A robust and reproducible animal serum-free culture method for clinical-grade bone marrow-derived mesenchymal stromal cells. Cytotechnology 68(4): 891-906.

44. Strandberg G, Sellberg F, Sommar P, Ronaghi M, Lubenow N, et al. (2017) Standardizing the freeze-thaw preparation of growth factors from platelet lysate. Transfusion 57(4): 1058-1065.

45. Zimmermann R, Arnold D, Strasser E, Ringwald J, Schlegel A, et al. (2003) Sample preparation technique and white cell content influence the detectable levels of growth factors in platelet concentrates. Vox Sang 85(4): 283-289.
46. Weibrich G, Kleis WK, Hafner G, Hitzler WE (2002) Growth factor levels in platelet-rich plasma and correlations with donor age, sex, and platelet count. J Craniomaxillofac Surg 30(2): 97-102.

47. Klatte-Schulz F, Schmidt T, Uckert M, Scheffler S, Kalus U, et al. (2018) Comparative analysis of different platelet lysates and platelet rich preparations to stimulate tendon cell biology: an in vitro study. Int J Mol Sci 19(1): 212.

48. Bausset O, Giraudo L, Veran J, Magalon J, Coudreuse JM, et al. (2012) Formulation and storage of platelet-rich plasma homemade product. BioResearch Open Access 1(3): 115-123.

49. Marck RE, van der Bijl I, Korsten H, Lorinser J, de Korte D, et al. (2018) Activation, function and content of platelets in burn patients. Platelets 30(7): 1-7.

50. Schallmoser K, Bartmann C, Rohde E, Reinisch A, Kashofer K, et al. (2007) Human platelet lysate can replace fetal bovine serum for clinicalscale expansion of functional mesenchymal stromal cells. Transfusion 47(8): 1436-1446.

51. Mazzucco L, Balbo V, Cattana E, Guaschino R, Borzini P (2009) Not every PRP-gel is born equal. Evaluation of growth factor availability for tissues through four PRP-gel preparations: Fibrinet, RegenPRP-Kit, Plateltex and one manual procedure. Vox Sang 97(2): 110-118.

52. Heijnen HF, Schiel AE, Fijnheer R, Geuze HJ, Sixma JJ (1999) Activated platelets release two types of membrane vesicles: microvesicles by surface shedding and exosomes derived from exocytosis of multivesicular bodies and alpha-granules. Blood 94(11): 3791-3799.

53. Torreggiani E, Perut F, Roncuzzi L, Zini N, Baglì SR, et al. (2014) Exosomes: novel effectors of human platelet lysate activity. Eur Cell Mater 28: 137-51.

54. Huber HJ, Holvoet P (2015) Exosomes: emerging roles in communication between blood cells and vascular tissues during atherosclerosis. Curr Opin Lipidol 26(5): 412-419.

55. Guo SC, Tao SC, Yin WJ, Qi X, Yuan T, et al. (2017) Exosomes derived from platelet-rich plasma promote the re-epithelization of chronic cutaneous wounds via activation of YAP in a diabetic rat model. Theranostics 7(1): 81-96.

56. Chandler WI (2013) Microparticle counts in platelet-rich and plateletfree plasma, effect of centrifugation and sample-processing protocols. Blood Coagul Fibrinolysis 24(2): 125-132.

57. Engebretsen L, Steffen K, Alsousou J, Anitua E, Bachl N, et al. (2010) IOC consensus paper on the use of platelet-rich plasma in sports medicine. Br J Sports Med 44: 1072-1081.

58. Milano G, Deriu L, Sanna Passino E, Masala G, Manunta A, et al. (2012) Repeated platelet concentrate injections enhance reparative response of microfractures in the treatment of chondral defects of the knee: an experimental study in an animal model. Arthroscopy 28(5): 688-701.

59. Khoshbin A, Leroux T, Wasserstein D, Marks P, Theodoropoulos J, et al. (2013) The efficacy of platelet-rich plasma in the treatment of symptomatic knee osteoarthritis: a systematic review with quantitative synthesis. Arthroscopy 29(12): 2037-2048.

60. Di Martino A, Di Matteo B, Papio T, Tentoni F, Selleri F, et al. (2019) Platelet-rich plasma versus hyaluronic acid injections for the treatment of knee osteoarthritis: results at 5 years of a double-blind, randomized controlled trial. Am J Sports Med 47(2): 347-354.

61. (2011) The International Cellular Medical Society. Platelet rich plasma guidelines. Best Practices Standards in Cell Based Medicine. Section X. 
ISSN: 2574-1241

DOI: 10.26717/BJSTR.2020.32.005290

Vicente Mirabet. Biomed J Sci \& Tech Res

(c) 9 This work is licensed under Creative

Submission Link: https://biomedres.us/submit-manuscript.php

\begin{tabular}{ll} 
BIOMEDICAL & Assets of Publishing with us \\
RESEARCHES & - Global archiving of articles \\
- Immediate, unrestricted online access & - Rigorous Peer Review Process \\
\hline
\end{tabular}

